\title{
PDGFD wt Allele
}

National Cancer Institute

\section{Source}

National Cancer Institute. PDGFD wt Allele. NCI Thesaurus. Code C124879.

Human PDGFD wild-type allele is located in the vicinity of $11 \mathrm{q} 22.3$ and is approximately

$257 \mathrm{~kb}$ in length. This allele, which encodes platelet-derived growth factor D protein, plays

a role in growth factor signaling, embryonic development, cell proliferation, wound healing and angiogenesis. 